\title{
On Contradictions in the Assessment of Information and Their Impact on E-Government and E-Health Services and Platforms
}

\author{
Tomasz Kulisiewicz \\ Centre for Studies on Digital Government, Poland
}

\begin{abstract}
Purpose/thesis: The article analyzes the contradictions and inconsistencies in the assessment of information and information architectures in Polish e-government and e-health services and platforms. The thesis is that the nature and role of information and the relations between information structures, information media and information systems are not properly understood by legislators and public institutions commissioning IT systems. This leads to difficulties in implementing e-government and e-health systems and platforms and a low rate of use of their services by the citizens and entrepreneurs Approach/methods: In order to prove this thesis a number of systems and platforms were examined. The systems chosen for analysis are these having the highest number of users and were expected to fulfill the needs both of the citizens and public institutions.

Results and conclusions: The examples analyzed show that there is a need to design, develop and introduce totally different e-government services. These new services should correspond with immaterial information structures and systems, not trying to reflect and 'computerize' the 19th century paper-oriented administration.

The goal of implementing IT in public institutions should be the assistance in fulfilling their main functions - serving the users. The improper understanding of information architectures results in additional burdens for all parties involved, instead of bringing improvements in the quality of public services. Originality/value: In author's opinion the relation between information structures and the rules of building information and IT systems in public administration is not understood properly. The results are the difficulties and problems in implementing and using the IT systems of public administration. On the other hand, formulating sound foundations for IT systems of public administration seems to be outside the main area of interest of the information studies. The article tries to bridge the gap between these two areas.
\end{abstract}

\section{Keywords}

E-government services. E-health services. Information Architecture. Information platforms. Information structures. Poland.

Received: 30.09.2014. Revised:02.11.2014. Accepted: 12.11.2014.

\section{Introduction}

In the author's view the problems observed in the implementation of e-government and e-health services in Poland as well as many other countries mainly stem from the contradictions and inconsistencies in the assessment of information and information architectures by public institutions. 
The foundation of information systems of any organization consists of information entities, structures and relations. On this foundation the procedures (algorithms) can be defined and the IT system can be designed in-house or commissioned externally and implemented in the organization. This is true for any organization, so it is true for public administration and any other public institution serving clearly defined purposes and having clearly defined aims and tasks. In the case of business entities, sources of information entities (data objects), information structures and relations fall within the category of business aspects, activities and aims of the company. In public administration the aims and procedures are defined by legislation. Thus, the design and implementation of the public administration IT systems relies crucially on the proper understanding and assessment of information, its architectures and structures, by all stakeholders: legislators, executives and civil servants of all levels of public administration. In this context it is worth to recall the definition of information:

\begin{abstract}
Information is data that has been processed into a meaningful form. Seeing it this way, information is an assemblage of data in a comprehensible form capable of communication and use; the essence of it is that a meaning has been attached to the raw facts (Feather \& Sturges, 2003, 244).
\end{abstract}

It can be added that this assemblage of data in a comprehensible form always has its structure which has to be addressed and reflected in an IT system processing this information.

\title{
2. Basic contradictions
}

The contradictions and the misunderstanding regarding the role of information (not to mention its structures, architectures and rules governing it) can be noticed at the starting point of all information systems of public administration - at the level of legislation. This statement is supported by the personal experience of the author, gathered during his professional activities, especially during his work with a team measuring administrative burdens in Poland as part of the project initiated by the Ministry of Economy in the years 2008-2010 and then during the trainings for civil servants in the years 2010-2011 ${ }^{1}$ (Kulisiewicz, 2013). The main preparatory task was an analysis of 482 pieces of legislations (acts and ordinances) and mapping them into formal structures in order to find and classify administrative obligations. This mapping of approx. 6200 obligations served as the basis for computing the time needed to fulfill the obligations, the cost of this fulfillment borne by entrepreneurs and the share of this cost considered an administrative burden. In order to accomplish this task, the structure of a given piece of legislation had to be analyzed, the obligations found and assessed. In the process, the lack of unified structures of the legislative acts could be clearly seen. The obligations of those who have to meet the given regulation can be found at the very beginning of the document, at its very end, spread all over in various places, in various forms (active or passive mode etc.). There are no clear decision points - whether in a given situation the entrepreneur should observe a given rule

\footnotetext{
${ }^{1}$ It is worth to notice that during 3 years since the end of 2011 (the end of the trainings mentioned) there were new technologies introduced in design and development of IT systems, but the practice of preparing regulations defining the foundations of information systems for public administration in author's opinion has not improved accordingly.
} 
or may not observe it, what the conditions are etc. Neither situations nor conditions are clearly defined; they are not following strictly defined sequences. The general problem is that there are no unified dictionaries and indexes of definitions, conditions, rules, decision points. This picture confirms the basic issue which has been emphasized by Polish IT specialists since the early 90s, when after 1989 the new system of regulations and legislations was built as a result of the radical change in Poland's political, economic and regulatory systems. The IT experts called for "algorythmizable regulations" - with properly defined information objects, structures and rules (PIIT \& PTI, 1999). If these objects, structures and rules are present in a legislative act, it is possible to build the appropriate IT system in a given IT environment (hardware platform, operating system, development tools etc.).

The problem with legally defining proper information structures and procedures can be demonstrated on the examples of some of the biggest Polish public information and IT systems. For the analysis presented in the Section 3. we chose these systems that have the highest number of users and are expected to fulfill the essential needs of citizens and public institutions.

Another major contradiction in the assessment of information stems from the incapability to (mentally) separate the information from its carriers - stone and clay tablets, papyruses, paper manuscripts and printed documents, books and registers. Strictly speaking, the basis for the decisions to be made by the authorities was always the information itself and not its carrier, but until the emergence of IT systems the two were inseparable. This inseparability is no longer present in IT systems where the information is carried electronically, independently of its carrier. It may be coded, decoded and transformed from one form into another - from the holes in the old punched cards to the electromagnetic waves of the wireless systems and the light impulses of the fiber-optic cables - without losing its content and essence. One thing, however, has not changed - the administration's need for information in order to fulfill its duties. Nowadays, it does not mean the possession of information on its carriers but the access to the information collected in registers and databases of public administration and the information provided by the citizens, entrepreneurs, NGOs, public institutions - using any appropriate channels and carriers.

The misunderstanding of the distinction of the information and of its carrier results in the requirement to possess certification or testimonials on paper, mentioned in the previous section, stems from the general attitude of the public administration and its practices based on the century-old model of relations with the citizens. For centuries the authorities demanded that their subjects present proofs of legality of their activities, certificates of entitlement to their rights etc. Until the emergence of electronic documents and services, the information on the rights, entitlements and certifications could not be separated from its carrier - the paper document. This fact is reflected in the common practice of demanding certificates, testimonials and attestations (on paper) from entrepreneurs and citizens instead of having the public institutions check them online. It is still the everyday practice despite the fact that:

formally there is a law ${ }^{2}$ saying that no institution of public administration can demand any certificates to prove the facts known to this institution or the facts which this institution may ascertain through its own registers, other data or documents presented by the person involved (Ustawa, 1960);

${ }^{2}$ Article 220 of the Polish Code of Administrative Procedure. 
the basic registers containing the information which the public administration may require from the citizens or entrepreneurs in various procedures are available online.

For instance a company attending a public procurement tender has to produce a paper proof of registration, a document from the tax office proving that it has no unpaid taxes and a certificate from the ZUS ${ }^{3}$ agency confirming that it has no delays in payments of its employees' pension and health insurance fees ${ }^{4}$. There are various formal regulations or even informal practices regarding the validity period of such paper certificates (in some cases 30 days, in other -90 days). As opposed to some of these paper certificates, all official registers are equipped with appropriate authentication mechanisms - consequently, the information demanded and obtained from these registers is far better authenticated and more up-to-date compared to any paper document needed in order to confirm the company's information or status.

\section{Social insurance system - legislation vs. architecture}

The example of a problem with legal definitions of proper information structures is the IT system of the ZUS, the Polish Social Insurance aAgency. The system collects insurance premiums and other fees, managing social security and dealing with payments. Before the change, pension and social security fees and premiums were collected in a way which reflected a structure of mainly state-owned economy. Enterprises were paying general pension premiums for all their employees (fees for approx. 9.5 million employees were collected in that form); the state pension agency was paying pensions based on generally set rules. The pension reform of 1998 radically changed the social insurance system: from 1999 onwards, fees were to be collected individually from each of the 13 million employees (one part was deducted from the employee's salary, the second part was paid by the employer) and kept by the social security agency on the insured person's individual account. In order to illustrate the difference: in the old pension system, the number of declarations processed each year was in a range of 18 million, in the system of individual accounts this number is approx. 260 million (Dagiel, 2005). The structure of the new information system had to be designed from scratch. Of course it could be done - designing and implementing such an IT system is an extensive and complicated task, but not unusual and extremely rare in the practice of building IT systems. Theoretically, all information structures, rules, procedures for an information system as foundation of an IT system were defined in law. The main problem was the attitude of the legislators and the leadership of the ZUS agency. The legislation came into force on the 1 January 1999 and on this date the registration of employers and employees insured in the new system had to be started. In December 1998, quite unexpectedly, extensive changes of

\footnotetext{
${ }^{3}$ ZUS = Zakład Ubezpieczen Społecznych; the official English name of the agency is the Social Insurance Institution.

${ }^{4}$ The form of the ZUS certificate is defined in law - it has to be printed as an official form with a 9-digit serial number, an 18-digit identifier, the official stamp of the issuing bureau of the ZUS agency and the signature of the authorized person. As there is no exception to this rule, even the ZUS agency itself demands such a certificate in its tenders for services and supplies - instead of checking the status of the payments in its own systems. In the case of a civil law partnership, the certificate is demanded separately from each of the partners (ZUS, 2012).
} 
the new law were introduced and passed by parliament. The most crucial amendment was the introduction of an extremely complicated system of healthcare fees and payments (sick leave allowances, disability payments etc.). Until 1997, healthcare insurance was managed by the general income tax system. This is a common solution in many countries: as healthcare fees are usually tax-deductible, it makes sense to manage them together with taxes using tax IT systems. The legislators seemingly did not have the slightest idea that such an extension of the information system's main functionality would require extensive changes in its structure. In order to collect data on sick leaves, a huge separate system of data collection and proofing had to be added to the architecture of the information system.

In 1998 the leadership of the ZUS changed. The first thing that the new leadership was to transform was the main concept of the IT system and its data processing architecture. The original concept was a client-server architecture with dumb terminals at the local contact points of the agency, regional data centers for daily routine tasks and a server-cluster at the headquarters for processing data needed for the general management, financing and planning purposes of the whole pension system. The winning offer was prepared accordingly, the tender won by the Polish software house Prokom Software (now Asseco Poland), which had been developing and implementing Unix client-server systems for years. The software house had started to design the IT system (called $\mathrm{KSI}^{5} \mathrm{ZUS}$ ), when, for reasons unknown, the whole concept of information structure was modified by the new leadership of the ZUS and included in the annex to the contract. The annex described an entirely different architecture - mainframe-oriented, with all the data processing executed centrally in the main data center of the ZUS.

The system was developed and implemented at a huge cost, estimated at PLN 3 billion (approx. EUR 750 million) (Doliniak, 2010). It is one of the largest and most complex systems of its kind in Europe, despite the fact that Poland, with its 38 million inhabitants, 1.8 million active commercial entities and 13 million insured persons, is only the sixth in the EU in terms of the number of inhabitants and employees. The functions needed to cover such a wide range of services - starting with registering a new employee, through paying their sickness, maternity, compensatory, care allowances, managing their individual pension account, processing their payments for retirement, the disability and survivors' pensions, up to the funeral grants - were formalized in a thousand kinds of forms and printouts. The KSI ZUS system was even awarded a prize of the eEurope Awards for eGovernment - 2005 in the category of "Enabling eGovernment", given in the years 2003-2005 for outstanding solutions in the fields of e-health e-government by the European Institute of Public Administration. The jury appreciated the scale and the impact of the system:

This initiative was judged extremely impressive, involving large scale institutional change (EIPA, $2005,1)$

At the same time this complexity - the result of an extremely wide range of tasks described in the law - was the source of difficulties in the development of the KSI ZUS system and in the use of its e-services.

In 2012, a Web service was added to the KSI ZUS system, allowing individual access of registered employers and individual employees. As there are thousands of procedures with

\footnotetext{
${ }^{5}$ KSI ZUS = Kompleksowy System Informatyczny ZUS - ZUS Integrated IT System.
} 
separate forms, the developed and implemented Web service overlay (called PUE ZUS ${ }^{6}$ ) is equally complicated. Despite it being obligatory for employers and intensively promoted in media campaigns, there are only approx. 800 thousand users registered at the Web system out of 1.8 million active companies and 13 million employees (ZUS, 2014).

The main problem of the PUE ZUS e-services is that they reflect the complex data structures and data formats of a system designed for use by the professional personnel of the ZUS local contact points, employees of HR departments of bigger companies or trained outsourcers servicing SMEs. Individual users and one-man companies are hardly using the e-services of PUE ZUS. In the author's opinion, the main reason for this is that the PUE ZUS system does not follow the rules implemented successfully in internet banking. The transactional system of internet banks can be used easily not only by professional bank cashiers and operators but by ordinary users: entrepreneurs, white - and blue-collar workers, students, pensioners - all those with a basic competence to use a Web browser. After some unsuccessful pilot projects in the early 90s, nobody tried to force non-professional users to operate cashier-desk level internal banking transaction systems.

It has to be noticed that for the ordinary users of PUE ZUS there is no interface to the services of the NFZ7 , despite the fact that the KSI ZUS system collects data for the healthcare system too. There is even a warning displayed in PUE ZUS saying that the fact that PUE ZUS indicates a positive healthcare insurance status means nothing, as the status of the same person in the NFZ's own system may be different (negative/not insured, which means: not entitled to the services of the public healthcare system). From the point of view of the users this is an inconsistency of an information system: PUE ZUS, an e-service of a public institution, does not support functions dealing with health insurance - the functions needed (and expected) by users - despite the fact that all the information on the status of insured persons is in the system registers, collected and updated each month.

\section{Vacuum instead of structure}

Usually the problems in introducing e-government services occur when one tries to bring computers into the traditional administrative procedures, where the information needed to make an administrative decision cannot be separated from its carrier - a paper document. The IT system reflecting a paper document-centric information system and its procedures is ineffective and seen as redundant, bringing additional burdens on all parties involved - administration, citizens and entrepreneurs alike. There are the cases when the situation can be worse: when the IT system is developed and implemented with no proper foundation, in a kind of "information vacuum" - with neither electronic nor "traditional" paper-centric information architecture.

In 2011, a new healthcare reimbursement act and a connected decree of the Minister of Health introduced an obligation for general practitioners (GPs) to check the health insurance status of their patients. GPs were made financially responsible for confirming the status of the patient and providing medical treatment and prescribing medicines with the

\footnotetext{
${ }^{6}$ PUE ZUS = Platforma Usług Elektronicznych ZUS - ZUS Platform of Electronic Services.

${ }^{7}$ NFZ = Narodowy Fundusz Zdrowia - National Health Fund.
} 
correct refund rates - dependent on this status. GP professional organisations protested explaining that since GPs have no means of checking the health insurance status, they would demand a documented proof of status from the patients. The problem was that there was no general document proving the status - the introduction of a separate health card was stopped years before, after its partial implementation in the Silesian Voivodeship, one district of Warsaw and one of the capital's small suburban communes. Another project to include it in the chip of a new personal ID card was dropped in 2012 as a result of substantial changes introduced in the original pl.ID project ${ }^{8}$. So a quick fix was introduced in the form of an online system (called eWUS' ${ }^{9}$ ) accessible by all clinics, hospitals and GPs. With the help of the eWUŚ system the administrative personnel of a clinic or a GP himself could check within seconds whether the patient's status is "green" (valid public health insurance) or "red" (no valid insurance). From the technical point of view the eWUŚ system from the beginning has been coping easily with the workload even during peak hours (in the morning, when the majority of patients have doctor's appointments, and at midnight, when each night all hospitals check the status of all their patients). The workload has never exceeded 300 checks per minute. For the sake of comparison it can be mentioned that in the first half of 2013 in Polish card payment systems there were approximately 71 card transactions/second (4.2 thousand transactions/minute) (NBP, 2013). The UTP system (Universal Trading Platform), the main IT system of the Warsaw Stock Exchange, can deal with 20 thousand transactions per second and up to 15 million transactions per session in its basic configuration ${ }^{10}$ (GPW, 2013). This means that there are IT systems available which can deal with far higher loads than these of eWUŚ.

As opposed to the technical efficiency of the IT system, the information system served by eWUŚ demonstrates negligence in the design of the information architecture. The lack of underlying information structure can be observed in the case of eWUŚ indicating a "red status". The patient has to prove their insurance status by bringing various documents confirming that entitle them to use public healthcare services. The patients can also fill out a form stating that they are sure of their "green" status, but then they still have the obligation to prove it after handing over this statement-form to the medical personnel. It means that the patient has to collect all the documents required before the introduction of eWUŚ: obtain them from their employer or a local ZUS branch and send them or bring them personally to the regional NFZ office.

The lack of understanding of the need for information infrastructure can be proved by analysing the history of the documents (identifiers) required to confirm the patient's identity and their insurance status. Before 1995, basically only one document was needed: a personal 112-page insurance booklet containing registration of entitlement (stamped by the employer or other institutions once in a defined time period, i.e. every three months). Around 1995 the booklet changed its form (becoming a white booklet with separate

8 The main change introduced in the original pl.ID project was a cancellation of the electronic layer in the ID card (microchip). Instead the modernization of the systems of reference and additional registers and of its server infrastructure was extended (MSW, 2013).

9 eWUŚ = Elektroniczna Weryfikacja Uprawnień Świadczeniobiorców - Electronic Verification of the Entitlement for Public Healthcare.

${ }^{10}$ UTP is scalable: for each new Trading Unit server the capacity of the system increases by 10 thousand transactions per second. 
coupons playing the role of "money" - the patient "paid" the clinic or the GP with the coupon, the coupon served as proof for the financing institution that the service was carried out). In 2010, the booklets had to be exchanged for new ones due to the change of the first 2 digits in the booklet's serial/identifier number. The exchange process had not been completed when the issuing of the new booklets was stopped midway, for no rational reasons. Now the patient had to prove their status by various means: personal ID together with a pensioner card, student card, confirmation of payment of the health-insurance fee etc. The national health service seemed to be unaware that the booklet played another, equally important role: it was the "container" of the patient's medical data. The elimination of the booklet demolished the traditional paper medical record system. The old booklet contained the patient's medical history and other data. Dropping it resulted in a situation where medical records are dispersed all over the clinic, hospitals and other places visited by the patient. The records are now inconsistent, with no time continuity. Interestingly enough, in some Polish cities there were protests of the patients who very rationally assessed that this was not only a change of documents proving the patient status, but also a demolition of the information system. The situation remained unchanged until the introduction of the eWUŚ system. After the system was introduced, each "red status" patient had to prove their health-insurance status despite the fact that the relevant information was (or should have been) present both in the huge KSI ZUS system and in the separate database of all insured persons developed and run by the NFZ.

This problem of the information demanded by patients is expected to be partially solved by IKP ${ }^{11}$, the implementation of the Electronic Health Record (EHR) for each person entitled to public healthcare. It should contain all medical data of a person, together with their health-insurance status. IKP is a module of an integrated healthcare information system based on RUM. The IKP module was tested in 2011 in Cracow and some other cities, on a very limited sample of patients ${ }^{12}$. Parallel to this pilot project, the system of electronic prescriptions was tested. Neither was well received by doctors and pharmacists. Because of the regulations demanding paper form of all documents (including prescriptions), during the test of the system everything had to be done doubly: using the official paper documents and electronically, with additional data collected during the test. This duality brought additional burdens on all parties involved: doctors, pharmacists and patients. As there was no compensation for these additional burdens, neither for doctors nor for pharmacists, the test was hardly accepted (one could say that there was even a resemblance to the historical Luddite attitude - in the e-prescription project in the Lubuskie Voivodeship, out of several hundred doctors, clinics and pharmacies only 16 GPs, 4 clinics and 14 pharmacies signed for the pilot project. The representatives of the local organizations of doctors and pharmacists even tried to avoid coming to the Center for Health Care Information Systems for consultations and assessment of the test project). The test was an additional burden for patients too: at the pharmacy they had to produce both the traditional paper prescriptions and their personal IDs in order for the pharmacists to register the transaction.

11 IKP = Internetowe Konto Pacjenta - Patient Internet Account. The eWUŚ system was to be a module of the whole IKP/RUM system.

12 RUM $=$ Rejestr Usług Medycznych - Register of Medical Services. 
The information on the health-insured persons' insurance status, medical treatments obtained, prescriptions issued and medicines bought in pharmacies, and all the treatment costs, medicine refunds etc. is presented to registered patients by another Web service (a separate module of IKP/RUM) called ZIP ${ }^{13}$. ZIP is a passive information system - the only active service consists of changing the user's password. One of the aims of ZIP was to allow patients to check whether their account had only been charged for treatments and medicines they really had obtained (anti-fraud function), but there is no messaging nor any active form of reporting to the NFZ if a patient does notice fraud or a mistake. It also has to be noted that the ZIP system does not allow one to book any kind of medical appointments. Theoretically, the average length of the waiting list for a given treatment can be checked in all hospitals and clinics which have contracts with the NFZ (as they have to report it to the NFZ), but these lists are accurate only to the extent of the reporting obligation (once a month). Moreover, one can check one's allocation to a family doctor and nurse (the Polish public healthcare system pays doctors and nurses based on the number of patients registered/allocated to them) but cannot change it on-line. The explanation for the relative popularity of ZIP - in August 2014, 13 months after its introduction, there were approx. 900 thousand registered users - (Rynek Zdrowia, 2014) despite its obvious shortcomings is probably that the system constitutes the only possibility for citizens to check their health-insurance status on-line.

The misunderstanding of the relation between information and the IT system can be demonstrated on the example of the obligatory documents needed for obtaining an EKUZ card $^{14}$ issued by the NFZ. In order to get a card, one should produce proof of valid health insurance. Before introducing the eWUŚ system, this would have been a formal document issued by an employer, proof of banking transfer of the monthly insurance fee in the case of entrepreneurs, a pensioner or student card (in the case of students - together with a formal certificate from their university) - the same proofs of eligibility for public healthcare as before the introduction of the eWUŚ system. As eWUŚ has been introduced as a way of confirming the patients' insurance status for public healthcare institutions, the general public rightly expected that the local NFZ bureaus issuing EKUZ cards would use this system to check the validity of health insurance. This was not the case: the obligation of proving one's status by bringing all the documents as before was not removed. The explanation of the NFZ was that the register of insured persons cannot be used for this purpose. The general public could neither understand nor accept the explanation that the National Healthcare Fund cannot use a register run by the National Healthcare Fund for this purpose. The source of this totally false explanation presented by the NFZ was the NFZ officials' misapprehension of the attitude and position of the non-professional users of the NFZ information system. The officials did not take into account that the end-users are dealing with the information system and not with the IT system. The non-professional user - citizen and entrepreneur - needs and uses the information provided by the information system, neither knowing nor caring about registers, databases, files and data formats, IT systems or any other back-office elements.

\footnotetext{
$13 \mathrm{ZIP}=$ Zintegrowany Informator Pacjenta - Integrated Patient System.

14 EKUZ = Elektroniczna Karta Ubezpieczenia Zdrowotnego - European Health Insurance Card (EHIC).
} 


\title{
5. The lack of a clear structure
}

The lack of clear information structures is distinctly exemplified by ePUAP, the unified platform for e-government services considered very important in Polish public administration.

Before analyzing the case of ePUAP it is worth to recall the definition of the e-government. One of the most comprehensive definition has been worded by the World Bank: “E-Government' refers to the use by government agencies of information technologies (such as Wide Area Networks, the Internet, and mobile computing) that have the ability to transform relations with citizens, businesses, and other arms of government" (The World Bank, 2005). The reasoning for using ICT in public administration has been given i.e. in the Ministerial Declaration on eGovernment from 2009, referred to as The Malmö Declaration:

(The European governments)... use eGovernment to increase their efficiency and effectiveness and to constantly improve public services in a way that caters for users' different needs and maximises public value, thus supporting the transition of Europe to a leading knowledge-based economy (European Commission, 2009, 1).

One of the main means of providing e-government services is the single point of access. The concept of single point of access is the crucial for supplying any service in any organizational structure as it substantially facilitates the use of the services, especially in complex systems. The ePUAP was intended to be a single point of access for all administrative procedures concerning the citizens and entrepreneurs. As it says in the description of the system on its Webpage:

\begin{abstract}
Electronic Platform of Public Administration Services (ePUAP) is a coherent and systematic action program designed and developed to allow public institutions make their electronic services available to the public. The website www.epuap.gov.pl enables defining citizen and businesses service processes, creates channels of access to different systems of public administration and extends the package of public services provided electronically (MAC, 2009).
\end{abstract}

The ePUAP website contains up to a thousand different services arranged by categories (services for citizens, for entrepreneurs, for administration), by administrative territories (voivodeships, counties, communes), or alphabetically. Unfortunately enough the possibility of executing the required administrative procedure depends on whether in the given commune the given procedure is available electronically or not: in some communes or towns there are some services available, in others - other services. This means that the availability of services depends on where one lives. It shows no pattern at all, despite the fact that the general corpus of laws regulating the various areas of public life for all the 2.5 thousand Polish communes is common and unified ${ }^{15}$. It can be understood that 6 years after the start of the ePUAP system the e-services dealing with local regulations may be at various stages of implementation, but the range of the e-services related to the procedures based on general legislation should (or at least could) be almost the same in all the communes. This is not the case with ePUAP which encompasses a patchwork of e-services implemented at various levels of administration, to a various extent, in various

15 Of course there are local regulations e.g. on sea fishing in the communes on the Baltic coast or on the pasturage of sheep in the communes in the Tatra mountains in the south of Poland. 
forms. Analyzing the services available on ePUAP one can say that the only e-government services introduced universally are:

- the official electronic mailbox for all public institutions obliged to have one by the Polish Act on the Informatization of Public Institutions;

- the general motion/letter to public institutions.

The side-effect of the lack of unified information structure underlying the ePUAP was the presence of e-services covering public administration "services" that make no sense. One such example is the application for the certificate of registration in the CEIDG - the Central Registration and Information on Business. The e-service for issuing such a certificate is available in 16 communes and towns (out of approximately 3 thousand localities present on ePUAP). One cannot find the purpose of this certificate as:

- by law, a certified printout from the CEIDG Registry that is equipped with a time-stamp constitutes an official certificate for the entities registered in this registry (The 2004 Law on the Freedom of Economic Activity in its Article 38. Section 5. even states that public institutions cannot demand any other certificate) (CEIDG, 2012);

- the registry is open to everybody - thus to public institutions as well; therefore any institution that wants to check whether a company is real, active, when it was registered, who the owner and the person entitled to act its behalf are, can do so at any time in the CEIDG Registry available as a Web-service.

The situation described is a consequence of building the platform for e-government services without defining the information structure and architecture of public information services. This means the foundation for a unified structure of e-services was missing.

A similar situation emerges in the case of the latest public information system, the Central Repository of Public Information. The Central Repository was provided for in the Access to Public Information Act as a tool for accessing and reusing public information (MAC, 2014). Despite the fact that the information resources to be shared in the Central Repository the institutions providing the information, data and meta-data formats - are defined in the ordinance of the Minister of Administration and Digitization (Rozporządzenie, 2014) and that the repository is equipped with APIs16, for non-specialists in need of finding and using public information, it seems to lack a clear structure that would be understandable for laymen.

\section{Conclusion - the need for a paradigm change}

The goal of implementing IT in public administration should be to assist public institutions in their main functions - serving the citizens and entrepreneurs. Yet in public perception the main goal of introducing IT in administration has been the improvement of the internal mechanisms of administration (the functioning of its back-office). The improper understanding of information architecture and the above-mentioned incapability to separate the information from its bearer may result in additional burdens and complications, quite often

\footnotetext{
${ }^{16}$ API - Application Programming Interface is a specification, a part of a computer program or a set of functions or routines, which specifies operations, their inputs and outputs, data objects and types, and allows for cooperation and exchange of data with different software, which may be developed separately.
} 
for the administration itself - instead of bringing improvements in serving the citizens and helping to develop the economy.

The successful e-government systems are those introducing into public administration the model that proved a huge success in e-commerce and especially in e-banking (internet banking). The number of internet banking accounts used by bigger, middle-range and even small companies is higher than the number of companies. Companies usually have more than one account, depending for instance on the terms of loans and credits, interfaces with ERP systems etc., and use internet banking for all their banking accounts. Nowadays, even consumers and microcompanies (especially one-man firms behaving very similarly to consumers) have more than one account per capita/company. In 2013, practically all banking accounts in Poland offered Web access functionality, the number of active consumer-users was 12.4 million, the number of users from the SME sector - approximately 1.11 million (ZBP, 2014). A dynamic increase is observed in mobile banking - a system providing access to banking accounts via smartphones equipped with banking applications. According to the reports of the Polish Bank Association and other sources, in the 1st quarter of 2014 almost 2.4 million out of 12.4 million Polish users of e-banking were already using mobile banking (Bankier.pl, 2014). A few years ago mobile banking was practically non-existent, as are currently the mobile e-government services (called m-government) still at an embryonic stage.

E-banking provides an example how to design and implement successful and widely acceptable new services. The information needed in bank transaction systems, the information structures and information processing rules are basically the same in the internal banking system and the internet banking open to users, but the interfaces of banking systems for the public had to be thoroughly redesigned in order to provide and demand only the information needed by users and not to exceed such a level of complexity that could be assessed and used by laymen.

In the Communication of European Commission The European eGovernment Action Plan 2011-2015 there was a profound reasoning for developing and deploying innovative e-government services:

Governments need to provide better public services with fewer resources. (...) The emergence of innovative technologies such as'service-oriented architectures' (SOA), or 'clouds' of services, together with more open specifications which allow for greater sharing, re-use and interoperability reinforce the ability of ICT to play a key role in this quest for efficiency in the public sector (European Commission, 2010, 3).

According to these objectives there is a need to design, develop and introduce totally different e-government services. These new services should correspond with immaterial information structures and systems, not trying to reflect and'computerize' the 19th century paper-oriented administration. The new services should also conform to the nature of convergent electronic communications and the New Generation Networks (NGNs): information should be collected from the citizens, entrepreneurs and public institutions and sent to them by means of various technologies, in various forms and formats. Not only does such a system have to be compatible with any device used by all the parties to information exchange in a given moment and location, but it also has to cope with the socalled handover problem - when the user changes their location or device, the operation 
has to be seamlessly transferred to the new location/device, adapting to its formats and maintaining all the required security characteristics. This means, for instance, accessing an e-service using a hybrid TV interactive device with a huge UltraHD TV screen and in the next moment switching over to a smartphone with its five inch screen.

The greatest task and the greatest challenge for public administration is to develop active, two-way communication between the administration and the citizens - not only collecting data and sending back decisions, but accepting the ideas and solutions proposed by the citizens, consulting planned actions, reacting to the demands and issues raised, etc. - according to the new paradigm of participatory prosumer democracy. This new paradigm is referred to as New Public Management - decentralized, managed by objectives, consumer-orientated and employing within the government competition mechanisms and managing tools used widely in the private sector (Krynicka, 2006). New Public Management treats users of public services like customers and shareholders of public administration. This change of paradigm requires a profound change in the architectures and development of information and in the IT systems of public administration.

\section{References}

Bankier.pl (2014). Bankowość mobilna będzie coraz bardziej powszechna [online]. Bankier.pl, July 3 [18.07.2014], http://www.bankier.pl/wiadomosc/Bankowosc-mobilna-bedzie-coraz-bardziejpowszechna-3158172.html

CEIDG (2012). Applicable Legal Provisions [online]. Central Registration and Information on Business, June 15 [18.07.2014], https://prod.ceidg.gov.pl/ceidg.cms.engine/?F;824A23D4-ED30-4C86-B9FF-21477D3D34C4

Dagiel, D. (2005). Wspomagana komputerowo reforma systemu ubezpieczeń społecznych, czyli historia pewnego projektu [online]. Polska Izba Informatyki i Telekomunikacji, May 18 [27.11.2014], www. piit.org.pl/documents/10181/17239/4176.pps

Doliniak, K. (2010). Maszyneria Trurla za trzy miliardy [online]. Forbes.pl, April 23 [16.06.2014], http://www.forbes.pl/artykuly/sekcje/sekcja-wydarzenia/maszyneria-trurla-za-trzy-miliardy,2054,2

European Commission (2009). Ministerial Declaration on eGovernment [online]. Digital Agenda for Europe, November 18 [1.11.2014], https://ec.europa.eu/digital-agenda/sites/digital-agenda/files/ ministerial-declaration-on-egovernment-malmo.pdf

European Commission (2010). European eGovernment Action Plan 2011-2015 [online]. Digital Agenda for Europe, December 15 [21.09.2014], http://eur-lex.europa.eu/LexUriServ/LexUriServ. do?uri=COM:2010:0743:FIN:EN:PDF

EIPA (2005). eEurope Awards. [online]. European Institute of Public Administration, December 8 [25.10.2014], http://www.eipa.eu/eEurope_Awards/Winners_eGov2005.pdf

Feather, J.; Sturges, P. (2003). International Encyclopedia of Information and Library Science. London, New York: Routledge.

GPW (2013). Universal Trading Platform (UTP) - Nowoczesna platforma GPW [online]. Giełda Papierów Wartościowych [14.08.2014], http://www.gpw.pl/pub/files/PDF/foldery/Architektura_UTP.pdf

Krynicka, H. (2006). Koncepcja nowego zarządzania w sektorze publicznym (New Public Managment). Studia Lubuskie, 2, 193-202.

Kulisiewicz, T. (2013). Redukcja obciążeń administracyjnych a wybrane zagadnienia informatyzacji administracji publicznej. Roczniki Kolegium Analiz Ekonomicznych 29, 131-150.

MAC (2009). What is ePUAP [online]. Ministerstwo Administracji i Cyfryzacji. ePUAP [30.09.2014], http://epuap.gov.pl/ 
MAC (2014). About the Central Repository of Public Information [online]. Ministerstwo Administracji i Cyfryzacji. Centralne Repozytorium Informacji Publicznej [25.10.2014], https://danepubliczne. gov.pl/aboutUs\#question_4

MSW (2013). Projekt pl.ID. O programie pl.ID [online]. Ministerstwo Spraw Wewnetrznych [1.11.2014], http://obywatel.gov.pl/prezentacja-urzednik

NBP (2013). Ocena funkcjonowania polskiego systemu ptatniczego w I pótroczu $2013 \mathrm{r}$. [online]. Narodowy Bank Polski - System płatniczy [3.09.2014], http://www.nbp.pl/systemplatniczy/ocena/ ocena2013_1.pdf

PIIT \& PTI (1999). Rozwój Informatyki w Polsce - stan, zalecenia, perspektywy. Poznań-Warszawa: Polska Izba Informatyki i Telekomunikacji, Polskie Towarzystwo Informatyczne.

Rozporządzenie (2014). Rozporzadzenie Ministra Administracji i Cyfryzacji z dnia 26 marca 2014 r. $w$ sprawie zasobu informacyjnego przeznaczonego do udostepniania w Centralnym Repozytorium Informacji Publicznej [online]. Dz. U. poz. 491 [28.10.2014], http://dziennikustaw.gov.pl/ D2014000049101.pdf

Rynek Zdrowia (2014). Dzięki ZIP pacjenci coraz częściej wykrywają nadużycia [online]. Rynek Zdrowia, August 13 [11.09.2014], http://www.rynekzdrowia.pl/Finanse-i-zarzadzanie/DziekiZIP-pacjenci-coraz-czesciej-wykrywaja-naduzycia,143726,1.html

The World Bank (2005). Definition of E-Government [online]. The World Bank, May 18 [30.10.2014], http://go.worldbank.org/M1JHE0Z280

Ustawa (1960). Ustawa z dnia 14 czerwca 1960 r. Kodeks postępowania administracyjnego [online]. Internetowy System Aktów Prawnych [30.10.2014], http://isap.sejm.gov.pl/Download?id=WDU$19600300168 \&$ type $=3$

ZBP (2014). Bankowość internetowa i płatności bezgotówkowe - II kwartał $2014 \mathrm{r}$. Warszawa: Związek Banków Polskich.

ZUS (2012). Uzyskiwanie zaświadczeń o niezaleganiu w opłacaniu składek [online]. e-Inspektorat ZUS, styczeń 31 [20.10.2014], http://e-inspektorat.zus.pl/sprawy.asp?id_sprawy=158

ZUS (2014). ZUS Aktualności, wrzesień 26 [online]. Informacje, komunikaty [26.09.2014], http:// www.zus.pl/default.asp?id=1\&p=\&idk=2347

\title{
O sprzecznościach w ocenie informacji oraz ich wpływie na usługi i platformy związane z e-państwem i z e-zdrowiem
}

\begin{abstract}
Abstrakt
Cel/teza: Artykuł stanowi analizę sprzeczności i niespójności w ocenie informacji i architektury informacji w zakresie usług i platform dotyczących polskiego e-państwa i e-zdrowia. Uważa się, że natura i rola informacji oraz relacji łączących struktury, media i systemy informacyjne nie są właściwie odbierane przez legislatorów i instytucje publiczne zamawiające utworzenie bądź zakup systemów informatycznych. Skutkuje to trudnościami we wdrażaniu usług i platform e-państwa i e-zdrowia oraz niskim poziomem ich wykorzystania przez obywateli i przedsiębiorców.

Koncepcja/metody badań: W celu udowodnienia powyższego faktu przebadano szereg systemów i platform. Do analizy wybrano systemy o największej liczbie użytkowników, od których oczekuje się zaspokajania potrzeb, zarówno obywateli, jak i instytucji publicznych.

Wyniki i wnioski: Analizowane przykłady ukazują potrzebę projektowania, tworzenia i wdrażania zupełnie odmiennych usług związanych z e-państwem. Nowe usługi powinny korespondować z niematerialnymi strukturami i systemami informacyjnymi zamiast odzwierciedlać i „komputeryzować” XIX-wieczną koncepcję administracji osadzoną w realiach analogowych.
\end{abstract}


Celem wdrażania technologii informacyjno-informatycznych w instytucjach publicznych powinno być wsparcie w zakresie realizowania przez nie ich podstawowego zadania - służenia użytkownikom. Nieprawidłowe rozumienie architektury informacji skutkuje dodatkowym obciążeniem dla wszystkich zainteresowanych stron zamiast poprawiania jakości usług publicznych.

Oryginalność/wartość poznawcza: W opinii autora związki struktur informacyjnych oraz reguł budowania informacji i systemów informacyjno-informatycznych w administracji publicznej nie są rozumiane właściwie. Skutkuje to problemami we wdrażaniu i stosowaniu wzmiankowanych systemów. $\mathrm{Z}$ drugiej strony, budowanie zdrowych reguł wdrażania systemów informacyjno-informatycznych w administracji publicznej wydaje się pozostawać poza zakresem zainteresowania nauki o informacji. Artykuł stanowi próbę zmniejszenia bądź zamknięcia luki pomiędzy tymi dwoma obszarami.

\section{Słowa kluczowe}

E-państwo. E-zdrowie. Architektura informacji. Platformy informacyjne. Struktury informacyjne. Polska.

TOMASZ KULISIEWICZ obtained an MSc in Computer Science at the Budapest Technical University in 1974. From 1975 to 1980, he worked as a systems engineer at the computer center of the Polish road network administration. From 1982 to1992, he was employed in the Hungarian power industry, and subsequently served as deputy editor-in-chief and editor-in-chief of several Polish IT business magazines. Since 2002, he has been an electronic communications market analyst, co-founder of the Centre for Studies on Digital Government and the SME IT Association and Vortal, as well as a lecturer on economic and social impact of ICT.

Contact to the Author:

tomasz.kulisiewicz@cyfrowepanstwo.pl

Ośrodek Studiów nad Cyfrowym Państwem

ul. Narutowicza 105a lok. 3

90-145 Łódź 